\title{
Sir James in cyberspace
}

\section{Let there be public revelry - the OED takes to another dimension.}

\section{Oxford English Dictionary Online Oxford University Press: 2000. Annual

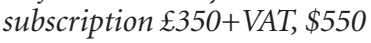 \\ Walter Gratzer}

It was said of Thomas Macaulay that he not only overflowed with learning but stood in the slop. This is precisely what happens when you first uncork the new online-only edition of the Oxford English Dictionary (OED), and allow it to spill a measure of its profligate riches over your feet.

The OED, let it be said, is an incomparable monument of scholarship, one of the wonders of our age. I began my exploration of its vast territories by checking some cherished etymological beliefs, or, as I now find, misapprehensions. Look up loo for instance and you find that it is first of all a card game; the description is detailed enough for you to be able to sit down to a hand or two with the characters in works by William Wycherley or Jane Austen, who cavort in the quotations. Then again, a loo (Obs. exc. Hist.) was "a velvet mask partly covering the face, worn by females in the 17th century to protect the complexion". The third loo is "the name given in Bihar and the Punjab to a hot dust-laden wind", and to prove it, there is a stirring passage from Kipling. And finally, a loo is indeed "a privy, a lavatory". Here the $O E D$ is sparing of etymologies, but vouchsafes that A. S. C. Ross examined possible sources in 1974 in the October issue of Blackwood's Magazine, wherein he concludes that it derived "in some manner that cannot be demonstrated from Waterloo"; no gardey loo, then (the cry of the Edinburgh housewives as they emptied their chamber pots into the street from the upper window)? Or even l'OO, from the two holes in a French privy door that allowed you to see whether it was occupied? Alas, it seems not.

Sidling towards science, I wandered at random among the units of measurementpascals, oersteds, newtons, Bohr magnetons, units SI and units obsolete - the OED embraces them all. But for a more stringent test I sought out the eccentric Dent Dictionary of Measurement and found first the unit of pain, the dol: this the OED effortlessly defined. Moving a little further from the beaten track, I challenged it with cran, the unit for the measurement of herrings, and was rewarded by the following definition: "A measure of capacity of fresh herrings as caught; fixed by the Fisheries Board at $37 \mathrm{fi}$ gallons (about 750 fish)". "Up to 1815," the dissertation continues, "the cran was measured by heaping full a herring-barrel with the ends taken out, which was then lifted,

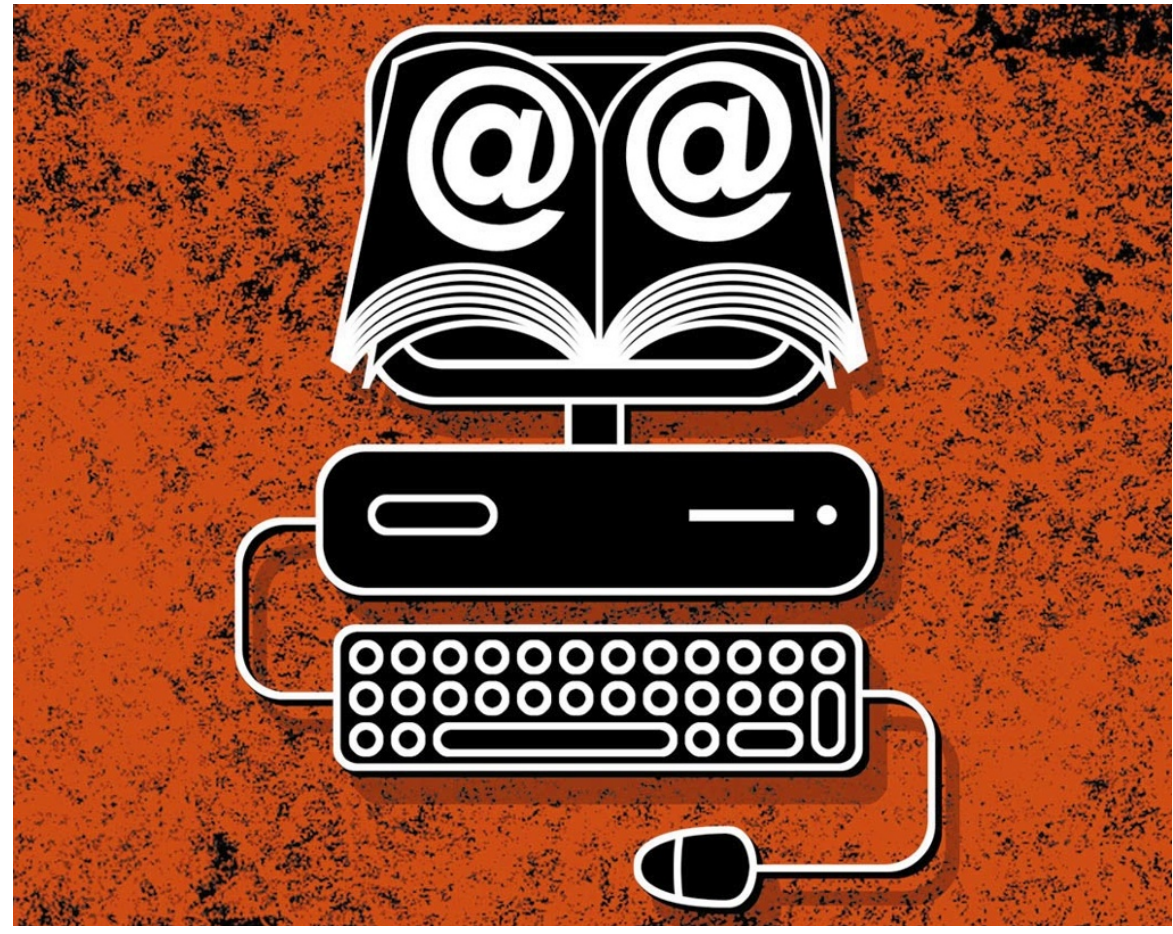

leaving the heap on the ground or floor. In 1816, the Commissioners for the Herring Fishery fixed the capacity of the 'cran' at 42 gallons, Old Wine Measure, which in 1832 was raised to 45 gallons, 42 gallons when 'pined' being found insufficient to make a barrel of bung-packed herrings." There is more, not forgetting the quotations. A cran is also a term (Obs.) for the crane and the heron. On the other hand, there is no mention of the cran, defined by Hobson-Jobson, the ebullient nineteenth-century dictionary of Indian and Malaysian words, as "A modern Persian silver coin". The Dent Dictionary also offers a list of collective nouns: wildfowl travel in sutes, turtles in dules and jellyfish in smucks. The OED lists none of these, but it concedes that a brood of ducks was at one time a badelyng, and of pheasants a nye.

Did the editors of Dent perhaps make up the others? Or could they all be usages so far decayed as no longer to count as words? For the $O E D$ is a living organism, which not only grows, but also presumably sheds detritus. The enterprise (originally The New English Dictionary on Historical Principles) was conceived in this sense by a group of Victorian scholars in 1857; their plan was to engage volunteers, allocating to each one a sector of the English literary and historical landscape in which to forage.

In 1878 the Oxford University Press was finally persuaded that the project had merit, and chose the redoubtable schoolmaster James Murray as editor. The task was not completed until 1928, long after Murray's death. It was never the founding fathers' intent to lay down rules of linguistic usage. The dictionary was to be authoritative, but not authoritarian, to observe and describe, not prescribe. Ambrose Bierce, in The Devil's Dictionary (Wordsworth), defined a dictionary thus: "A malevolent literary device for cramping the growth of a language and making it hard and inelastic".

The $O E D$ has been the very antithesis. It abjured from the outset any desire to emulate the French Academy, with its Forty Immortals, who in the eighteenth century saddled their language with the curse of the circumflex and even in our time were prepared to instruct scientists that an enzyme was feminine, when all French biochemists knew perfectly well that it was un enzyme. The OED does not spurn those neologisms that so affront the guardians of linguistic purity. Thus, as one of the definitions of hopefully it offers: "It is hoped (that); let us hope... orig. U.S. (Avoided by many authors)", it cautiously observes.

It is clear that the organism has been almost continuously updated, with the various additions, which followed the majestic second edition of 1985 in 12 volumes, with $\mathrm{CD}-\mathrm{ROM}$ as an option. The new online dictionary is still undergoing revision, a labour that will take another 10 years to complete. So far, only M-MAH is finished, and the editors concede that the OED's content of science may still be found in some degree wanting.

Look up scientist, then, and you will 
discover the history of the word from its first tentative appearance in 1834: an article in the Quarterly Review laments the fragmentation of science, as reflected in "the want of any name by which we can designate students of the knowledge of the natural world collectively ... some ingenious gentleman proposes that, by analogy with artist, they might form scientist ... but this was not generally palatable". In 1840 William Whewell (said to be the last man to know everything) re-invented the word and in time it stuck. But look down the column of adjoining entries on your screen and you can find what we were spared: "Sciencer, Obs. A professor of a particular science". And then there is the magnificent, and much-needed, conceit, "Scientaster [... after poetaster] A petty or inferior scientist", coined by the physiologist Michael Foster in 1899; a quotation follows from Foster's biography of Claude Bernard.

The physical sciences seem to me to do better on the whole than biology, perhaps because the corpus of knowledge is less diffuse. Here, under flavour, are the six flavours of quarks; string theory and superstrings get crisp definitions; Higgs appears, attached to boson, field, mechanism and particle; and, going back a little in time, Debye surfaces under Debye effect, Debye-Hückel theory, Debye-Scherrer method, Debye temperature and Debye unit. Here, too, is buckminsterfullerene, complete with a quotation from Harry Kroto in Nature. The besetting fatuity, still found in many dictionaries, of recording stoichiometric rather than structural chemical formulae has been largely but not entirely expunged, so the peptide melittin from bee venom comes out as $\mathrm{C}_{131} \mathrm{H}_{229} \mathrm{~N}_{39} \mathrm{O}_{31}$ (who counted?). Sulfur - in the American and now internationally sanctioned spelling - is not in evidence. Prefixes for large units do better than those for small: we find giga-and tera-, but not atto-and zepto-.

As to biochemistry, all the most familiar proteins seem to be present and quite a number of others, although some definitions (actin for instance) are in sore need of revision. We have transferrin, ferritin, laminin, reverse transcriptase, spectrin and ankyrin even, but no integrin, fibronectin, clathrin, calpain or G-protein. Oncogene and homeobox are in, but apoptosis is missing and so are $T$ cells or T-lymphocytes, genomics and indeed PCR. In the revised M-MAH sliver, I looked for and found magainin, first isolated from the skin of the "clawed toad" — but Xenopus, I am assured, is not a toad, but rather a clawed-toed frog. Missing is $\mathrm{MHC}$ (major histocompatibility complex), ubiquitous enough, arguably, to qualify for inclusion. Of course, the $O E D$ does not purport to be a textbook or encyclopaedia of science and somewhere must draw an arbitrary line between the barely useful and

the totally recondite, but among the lacunae are expressions that a journalist, for instance, might well want to track down.

The dictionary is diverting on misuses that have become irretrievably embedded in common speech. Parameter (first spotted in a mathematical tract in Latin by one $\mathrm{C}$. Mydorge in 1631) receives separate definitions in conic sections, crystallography, mathematics, electricity and statistics, but also "In extended use: any distinguishing or defining characteristic or feature ...", with a quotation, fittingly enough, from $\mathrm{New}$ Sociology ("We would then say that a social theory has a human-nature parameter" ah, so!). A quantum jump is not only a transition between stationary states of a quantized system, but more especially "transf., a sudden large increase or advance", also now known to politicians and estate agents as a quantum leap.

The online format of the OED is friendly and responsive. A click of the mouse will bring up or hide pronunciation, etymology, quotations (2.5 million of them and, to my mind, the greatest treasure of all) and a date chart showing the development and decline of usages. You may retrieve quotations from any one author, and relate them to particular words; you may bookmark entries and you may search for your favourite cliché ("sick as a ...”). If you are unsure of a spelling you can enter a question mark in the middle of your word or use an asterisk (wild card) to denote an undefined number of letters. This will allow you, if you are so inclined, to play word-games. So, for illustration, a reader in a newspaper recently asked whether any words existed in which a single consonant appeared three times in tandem. Well, a brief search of the OED for words of the type, 'sss' at once yielded bossship and one typo.

Today's science, with its headlong pace of progress and its ever-shifting frontiers, probably makes impossible demands of the OED's editors, and it will be interesting to see how they grapple with it between now and 2010 .

Meanwhile, we should celebrate a great and noble assertion of intellectual virtues and an inexhaustible source of pleasure, to those at least who can afford to or otherwise get at it. H. L. Mencken, journalist, lexicographer and sage, thought that the completion of the first edition of the OED in 1928 should be marked in Oxford by public revelry - "military exercises, boxing matches between the dons,

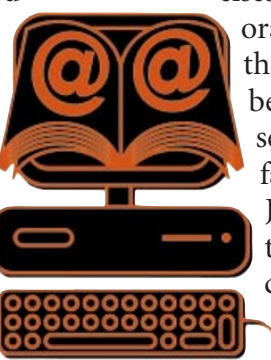

orations in Latin, Greek, English and the Oxford dialect, yelling matches between the different colleges, and a series of mediaeval drinking bouts". I fancy I can see the benign shade of Sir James Murray, surrounded by his team of indexers, celebrating out in cyberspace with a small dry sherry. Walter Gratzer is at the Randall Institute, King's College London, 26-29 Drury Lane, London WC2 5RL, UK.
When silence is not a true option

\section{The Woman Who Knew Too Much: Alice Stewart and the Secrets of Radiation}

by Gayle Greene

University of Michigan Press: 2000. 336 pp.

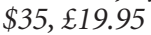

\section{Sunetra Gupta}

"Practising medicine without asking these larger questions is like selling groceries across the counter," said Alice Stewart when asked why, at the peak of a career in clinical medicine, she had decided to abandon it in favour of practising epidemiology.

In 1945, the importance of identifying the risk factors of infectious diseases was becoming obvious, and efforts had already been made to define and understand the ecological processes underlying the spread of infection. The Institute for Social Medicine had been established at the University of Oxford in 1943, reflecting the recognition that it might also be worthwhile to investigate the causes of non-infectious diseases such as cancer. These diseases might have "discoverable origins in social, domestic, or industrial maladjustment", according to the institute's founder, John Ryle. Ryle died in 1950, and the institute was diminished to the Social Medicine Unit and its building taken away. Stewart, who had been Ryle's assistant, was given a readership and made its head with a budget so small that there was "barely enough to light a gas fire".

It would have been perfectly possible for Stewart at this time to keep up some semblance of research and devote the rest of her time to her country garden, not to mention the lively intellectual circuit in which she had a singular place as the lover of the distinguished literary critic, poet and mathematician William Empson. However, according to her biographer, "epidemiological investigation engaged her like a piece of detective work", and in 1950 Stewart set about organizing a retrospective case control study to identify risk factors for childhood cancer on a grant of $£ 1,000$ from the Lady Tata Memorial Fund for Leukaemia Research.

"I spent those $\mathfrak{1} 1,000$ on railway fares traveling the length and breadth of England, going to each public health official, saying "here are the questionnaires, will you help?", said Stewart. From this incredible effort came the startling revelation that a single obstetric exposure to X-rays significantly increases the risk of an early cancer death. The Oxford Survey of Childhood Cancer, as it came to be known, continued for 30 years, beyond Stewart's retirement in 1974.

She relocated to the University of Birmingham, and found "an empty corridor 